\title{
COMPARATIVE STUDY OF ANTIMICROBIAL ACTIVITY AND PHYTOCHEMICAL SCREENING OF SERIAL EXTRACTS FROM LEAVES AND FRUIT OF AEGLE MARMELOS AND CARICA PAPAYA
}

\author{
JAISHREE SHARMA, PADMA KUMAR \\ Laboratory of Plant Tissue Culture and Secondary Metabolites, Department of Botany, University of Rajasthan, Jaipur (302004) \\ Email: sharmajaishri33@gmail.com
}

Received: 25 May 2017 Revised and Accepted: 02 Nov 2017

\section{ABSTRACT}

Objective: The present study was carried out to evaluate the in vitro antimicrobial activity of water, methanolic and pet ether extracts from leaves and fruit of A. marmelos and C. papaya.

Methods: Crude extract of leaves and fruit of Aegle marmelos and Carica papaya were prepared for series of polar solvents by hot extraction method in soxhlet then the extracts were first screened for its antimicrobial activity by "Disc Diffusion Assay" against medically important bacteria, plant pathogen and fungi. Fractions showing activities were then used to determine MIC (minimum inhibitory concentration) and MBC/MFC (minimum bactericidal and fungicidal concentration) by broth dilution and total activity were also calculated.

Result: Aegle marmelos shows comparatively significant antimicrobial activity than Carica papaya. However antimicrobial activity was found both solvent and organism dependent. Almost all the extracts of Aegle marmelos show an inhibitory effect against most of the test organism whereas the test extracts Carica papaya show an inhibitory effect against the very few test organisms. Lowest MIC values $0.0195 \mathrm{mg} / \mathrm{ml}$ were recorded against Roultella planticola and Klebsiella pneumonae indicate the significant antimicrobial potential of the test extracts. The high value of TA was recorded against Roultella planticola in both the plants. Data were analyzed by one way ANNOVA and values were considered significant at $\mathrm{P}<0.05$

Conclusion: The MIC and MBC/MFC values of Aegle marmelos showed its broad antimicrobial potential and is promising in the development of phytomedicine for antimicrobial properties then Carica papaya.

Keywords: Aegle marmelos, Carica papaya, Antimicrobial activity, Minimum inhibitory concentration, Minimum bactericidal concentration, Minimum fungicidal concentration Phytomedicine.

(C) 2017 The Authors. Published by Innovare Academic Sciences Pvt Ltd. This is an open-access article under the CC BY license (http://creativecommons.org/licenses/by/4.0/) DOI: http://dx.doi.org/10.22159/ijpps.2017v9i12.20228

\section{INTRODUCTION}

Antibiotics are promising in the treatment of microbial infection since their introduction but the inadequate and indiscriminate use of its leading to the selection of multi-resistant strains. Nowadays, synthetic antimicrobials are less effective to act against microorganism due to development of resistant to microorganism against commonly used antibiotics. The antimicrobial potential of plant extracts and essential oils is intended to delay this process through the emergence of new antimicrobial substances [1]. Therefore, the screening of medicinal plants is required for the development of novel agents advocating good efficacy against pathogenic microorganism with minimal side effects. For the present study, Aegle marmelos and Carica papaya were examined for antimicrobial attributes.

Aegle marmelos Linn. From Rutaceae is one such plant which is commonly known as Beal (wood apple plant) and is a sacred tree in Hindu mythology. Leaves, fruit, stem and root of this tree at all stages of maturity are used as ethno medicines against various human ailments [2]. Previous studies on Aegle marmelos [3-11] concluded to exhibit antidiabetic, antiulcer, anti-inflammatory, antioxidant, antimalarial, anticancer, anti-hyperlipidemic, anti-spermatogenic effects on various animal models by the crude extracts of this plant. Carica papaya belongs to family Caricaceae is an important medicinal plant. Fruit, leaves, the bark of this plant are used as medicine for treatment of various diseases like warts, constipation, amenorrhea, sinuses, eczema, glandular tumors, blood pressure, dyspepsia, cancer cell growth, diabetes, malaria, expel worms and stimulate reproductive organs, syphilis and gonorrhea [12-13].

A known set of eight pathogens were selected to examine the antimicrobial activity of Aegle marmelos and Carica papaya. S. aureus is a commensal found on the skin as well as in the nose and throat of a human. It causes a range of infections, from minor skin infections to abscesses, endocarditis and sepsis, cause of food poising induced by heat resistant enterotoxin A and it is one of the leading cause of nosocomial infections [14]. The Raoultella planticola is an environmental organism which causes infection such as bacteraemia [15], soft tissue infection [16], pancreatitis [17] and urinary tract infection [18]. Agrobacterium is a serious pathogen of walnuts, grape vines, and stone fruit. Pseudomonas aeruginosa is an opportunistic bacterium migrates from its natural environment, colonizing and infecting a wide range of organisms [19-20] and it is hard to treat it due to its ability to acquire resistance against multiple classes of antibiotics [21]. Aspergillus flavus cause invasive and non-invasive aspergillosis [22]. Trichophyton mentagrophyte requires keratin for growth and it can cause a variety of cutaneous infections in humans and animals which is considered to be anthropophilic or zoophilic in nature [23-25]. A comparative study of the antimicrobial activity was examined in terms of a zone of inhibition, activity index, minimum bactericidal concentration, minimum fungicidal concentration and total activity of an extract of Aegle marmelos and Carica papaya in three different solvents is presented in this manuscript.

\section{MATERIALS AND METHODS}

\section{Collection and identification of plants}

Leaves and fruit of A. marmelos and Carica papaya were collected from the campus of University of Rajasthan Jaipur (INDIA). Plants were identified by the senior taxonomist at Department of Botany, the University of Rajasthan and (voucher specimen no. of Aegle marmelos and Carica papaya are RUBL211335 and RUBL211336 respectively) were submitted in 'Herbarium', Department of Botany, University of Rajasthan.

\section{Test pathogens}

Total eight pathogens were screened of which Six bacteria and two fungi were selected which include Staphyllococcus aureus (MTCC- 
3610), Pseudomonas aeruginosa (MTCC-1934), Bacillus subtilis (MTCC-121), Klebsiella pneumonae (MTCC-4030), Agrobacterium tumifacian (MTCC-431), Roultella planticola (MTCC-530), Aspergillus flavus (MTCC-277) and Trycophyton mentegrophyte (MTCC7687). The pathogens were procured from IMTECH, Chandigarh (INDIA). Bacterial strains were grown and maintained on Muller-Hinton agar medium and the fungal strain was grown and maintained on Sabouraud Dextrose Agar medium.

\section{Extract preparation}

The crude extract of leaves and fruit of Aegle marmelos and Carica papaya were prepared for a series of solvents (water, methanol and pet ether) by hot extraction method [26] in soxhlet. Extracts were then first screened for its antimicrobial activity by "Disc Diffusion Assay" against medically important bacteria, plant pathogen and fungi fractions. These were further used to determine MIC (minimum inhibitory concentration) and MBC/MFC (minimum bactericidal concentration/minimum fungicidal concentration) by broth dilution.

\section{Drugs and chemical}

Streptomycin and ketoconazole and terbinafine were used as standard antibiotics for bacteria and fungi, respectively whereas petroleum ether, methanol and water used for extract preparation. Mueller-Hinton agar was used for bacteria and Sabouraud Dextrose Agar was used for fungi.

\section{Antimicrobial assay}

'Disc Diffusion Assay' method [27-28] was employed for antimicrobial screening of test extracts. The bacteria $\left(1 \times 10^{8}\right.$ $\mathrm{CFU} / \mathrm{ml})$ and fungi $\left(1 \times 10^{7} \mathrm{CFU} / \mathrm{ml}\right)$ were cultured in sterilized distilled water. Muller-Hinton agar and Sabouraud dextrose agar media were used for bacteria and fungi, respectively. These media were prepared and autoclaved at $15 \mathrm{lbs}$ pressure for 20 minutes for sterilization. The prepared media was poured into sterilized Petri plates and was cooled for solidification. The solidified media plates were seeded with the prepared culture suspensions. Sterilized filter paper discs of $6 \mathrm{~mm}$ diameter (Whatman no.1) were impregnated with $100 \mu \mathrm{l}$ of an extract of $10 \mathrm{mg} / \mathrm{ml}$ concentration to give a final concentration of $1 \mathrm{mg} / \mathrm{Disc}$. These discs were left to dry in vaccuo to remove residual solvent. The extract discs were placed on the seeded media plates along with discs impregnated with standard drugs (streptomycin for bacteria, ketoconazol for T. mentagrophyte and terbinafine for A. flavus) in the same (1 mg/disc) concentration. These plates were kept at $4{ }^{\circ} \mathrm{C}$ for $1 \mathrm{~h}$ for the diffusion of extracts into the media and thereafter were incubated at $37{ }^{\circ} \mathrm{C} \pm 2{ }^{\circ} \mathrm{C}$ for $24 \mathrm{~h}$ for bacteria and at $27{ }^{\circ} \mathrm{C} \pm 2{ }^{\circ} \mathrm{C}$ for $48 \mathrm{~h}$ for fungi. However, $T$. mentagrophyte was kept at $27{ }^{\circ} \mathrm{C} \pm 2{ }^{\circ} \mathrm{C}$ for $5-7 \mathrm{~d}$. Zone of inhibitions (IZ) produced by the extracts around the discs was measured and the 'Activity Index' (AI) was calculated by the established formula. The experiment was performed three times to minimize the error and the mean values were recorded for the final estimation of the resultant values.

$$
\begin{aligned}
& \text { Activity Index (AI) } \\
& =\text { Inhibition zone of the } \frac{\text { sample }}{\text { Inhibition }} \text { zone of the standard. }
\end{aligned}
$$

\section{Determination of minimum inhibitory concentration and minimum bactericidal concentration (MBC)/minimum fungicidal concentration (MFC)}

Minimum inhibitory concentration (MIC) was estimated for each plant extract showing antimicrobial activity against the given test pathogens. Broth microdilution method [29] was followed by determination of MIC values. Plant extracts were then re-suspended in acetone (acetone has no activity against test microorganisms) to make a final concentration of $10 \mathrm{mg} / \mathrm{ml}$. Two-fold serially diluted extracts were added to broth media of 96 wells of microtitre plates. Thereafter, a $100 \mu \mathrm{l}$ inoculum of bacteria was added to each well. Bacterial suspensions were used as negative control, while broth containing standard drug was used as positive control. Microtitre plates were then incubated at $37^{\circ} \mathrm{C}$ for $24 \mathrm{~h}$. Each extract was assayed in triplicate and each time two sets of microtitre plates were prepared, one was kept for incubation and another was kept at $4{ }^{\circ} \mathrm{C}$ for comparing the turbidity in the well of a microtitre plate. The MIC values were taken as the lowest concentration of the extracts in the well of a microtiter plate that show no turbidity after incubation. The turbidity of the well in the microtiter plate was interpreted as the visible growth of the microorganism. The minimum bactericidal and fungicidal concentration was determined by subculturing $50 \mu$ from each well. The least concentration of extract showing no visible growth on subculturing was taken as MBC and MFC.

\section{Total activity determination}

Total activity is the volume up to which test extract can be diluted without losing the ability to kill microorganisms. It is calculated by dividing the amount of extract from $1 \mathrm{~g}$ plant material by the MIC of the same extract or compound isolated and is expressed in $\mathrm{ml} / \mathrm{g} \mathrm{[30]}$.

\section{Statistical analysis}

Results are expressed as mean \pm SD $(n=3)$. Data were analyzed by one way ANNOVA and values were considered significant at $\mathrm{P}<0.05$.

\section{RESULTS}

Antimicrobial potency of serial extracts viz; water, methanol and pet ether was assessed using various parameters and quantity of extracts per gram of plant material. In the present study, six extracts were screened and all the extracts were found to be active against one or the other test pathogen. The results and the assessment of the antimicrobial potential of the serial extracts water, methanol and pet ether extract from leaf and fruit of the A. marmelos and C. papaya show significant activity against tested pathogens (table $1,2,3$ ). This study suggests the insignificant activity of pet ether extracts from both of the plants against all test pathogens.

A. tumifacians and T. mentegrophyte were found to be more resistant because none of the extracts shows activity against these two except water extracts of the fruit of Carica papaya. The aqueous extract of leaf of A. marmelos exhibits highest IZ value of $29.3 \pm 0.9 \mathrm{~mm}$ against $R$. planticola followed by an aqueous extract of the fruit of $A$. marmelos exhibiting IZ value of $29 \pm 2.82 \mathrm{~mm}$ against $K$. pneumonae. The aqueous extract of leaf and fruit of $C$. papaya does not show significant potential for these two pathogens with lower values $14.9 \pm 2.6 \mathrm{~mm}$ and $19.55 \pm .636$ $\mathrm{mm}$ for R. planticola and K. pneumonae respectively.

\begin{tabular}{|c|c|c|c|c|c|c|c|c|c|c|c|c|}
\hline \multirow[t]{3}{*}{ Pathogens } & \multicolumn{6}{|c|}{ Extracts of leaves of $A$. marmelos } & \multicolumn{6}{|c|}{ Extracts of leaves of $C$. papaya } \\
\hline & \multicolumn{2}{|c|}{ Water } & \multicolumn{2}{|c|}{ Methanol } & \multicolumn{2}{|l|}{ Pet ether } & \multicolumn{2}{|c|}{ Water } & \multicolumn{2}{|c|}{ Methanol } & \multicolumn{2}{|l|}{ Pet ether } \\
\hline & IZ & AI & IZ & AI & IZ & AI & IZ & AI & IZ & AI & IZ & AI \\
\hline B. subtillis & $15.5 \pm 0.1$ & 0.5 & $12.9 \pm 0.1$ & 0.42 & $9.2 \pm 0.3$ & 0.3 & $9.6 \pm 0.6$ & - & - & - & - & - \\
\hline S. aureus & - & - & $7.5 \pm 0.7$ & 0.3 & $9.5 \pm 2.1$ & 0.4 & & & $9.8 \pm 0.3$ & 0.4 & - & - \\
\hline A. tumifacian & - & - & - & - & - & - & - & - & - & - & - & - \\
\hline K. pneumonae & $13.5 \pm 3.5$ & 0.56 & $7.6 \pm 0.8$ & 0.32 & $9.5 \pm 0.85$ & 0.39 & $17.5 \pm .7$ & 0.6 & - & - & $10.065 \pm .1$ & 0.7 \\
\hline R. planticola & $29.3 \pm 0.9$ & 1.04 & - & - & - & - & $14.9 \pm 2$ & 0.6 & - & - & - & - \\
\hline P. aeruginosa & $8.5 \pm 0.7$ & 0.3 & $8.5 \pm 0.7$ & 0.33 & $9 \pm 1.41$ & 0.35 & - & - & - & - & $8.65 \pm .5$ & 0.6 \\
\hline A. flavus & - & - & $7.5 \pm 0.3$ & 0.4 & $8.45 \pm 0.4$ & & - & - & $7.1 \pm 0.4$ & 0.4 & - & - \\
\hline T. mentegrophyte & $7 \pm 0.1$ & 0.4 & - & - & - & - & - & - & - & - & - & - \\
\hline
\end{tabular}

Table 1.1: Antimicrobial activity of different solvent extracts of leaves A. marmelos and C. papaya

All values are mean \pm SD; $n=3$; IZ= Inhibition zone in $\mathrm{mm}$ (mean value; include $6 \mathrm{~mm}$ diameter of disc), AI= Activity Index (IZ developed by extract/IZ developed by standard), $(-)=$ No activity 
Among all the test extracts of $C$. papaya, aqueous extracts were found to be most active against $K$. pneumonae than any other tested pathogens. Water and methanolic extracts from both the plants were found most bioactive metabolite as antimicrobial activity was recorded against most of the tested pathogens. MIC and MBC/MFC values (table 2) were calculated from the plant extracts which were found active against the test pathogens. The MIC value ranges from 0.625-0.0195 mg/ml, MBC and MFC values ranges from $1.25-0.039 \mathrm{mg} / \mathrm{ml}$ and $0.625-0.156 \mathrm{mg} / \mathrm{ml}$, respectively. The lowest MIC value $0.0078 \mathrm{mg} / \mathrm{ml}$ was recorded against $R$. planticola and $K$. pneumonae indicates the significant antimicrobial potential of test extracts. The quantity of extracts per gram of the plant material and TA (table 3) were calculated. The high value of TA was recorded against $R$. planticola followed by $K$ pneumonae which shows their broad antimicrobial potential.

Table 1.2: Antimicrobial activity of different solvent extracts of fruit A. marmelos and C. papaya

\begin{tabular}{|c|c|c|c|c|c|c|c|c|c|c|c|c|}
\hline \multirow[t]{3}{*}{ Pathogens } & \multicolumn{6}{|c|}{ Extracts of fruit of A. Marmelos } & \multicolumn{6}{|c|}{ Extracts of fruit of $C$. papaya } \\
\hline & \multicolumn{2}{|l|}{ Water } & \multicolumn{2}{|l|}{ Methnol } & \multicolumn{2}{|l|}{ Petether } & \multicolumn{2}{|c|}{ Water } & \multicolumn{2}{|l|}{ Methnol } & \multicolumn{2}{|c|}{ Petether } \\
\hline & IZ & AI & IZ & AI & IZ & AI & IZ & AI & IZ & AI & IZ & AI \\
\hline B. subtillis & $20.35 \pm 0.49$ & 0.64 & $17 \pm 2.83$ & 0.53 & $17.5 \pm 2.12$ & 0.54 & $9.85 \pm 0.21$ & 0.392 & - & - & - & - \\
\hline S. aureus & $11.5 \pm 2.12$ & 0.52 & $10 \pm 1.41$ & 0.45 & - & - & $9.8 \pm 0.283$ & 0.426 & - & - & - & - \\
\hline A. tumifacian & - & - & - & - & - & - & $11.9 \pm 0.1414$ & 0.566 & - & - & - & - \\
\hline K. pneumonae & $29 \pm 2.82$ & 0.90 & - & - & $8.5 \pm 2.12$ & 0.26 & $19.55 \pm 0.636$ & 0.630 & $7.5 \pm 0.72$ & 0.242 & - & - \\
\hline R. planticola & $25.15 \pm 0.21$ & 0.93 & $15.5 \pm 0.71$ & 0.57 & $7 \pm 0.14$ & 0.25 & $9.9 \pm 0.141$ & 0.412 & - & - & - & - \\
\hline P. aeruginosa & $10.85 \pm 0.21$ & 0.37 & $16 \pm 0.21$ & 0.70 & - & - & - & - & - & - & - & - \\
\hline A. flavus & - & - & $9.35 \pm 0.49$ & 0.467 & - & - & - & - & - & - & - & - \\
\hline T. mentegrophyte & - & - & $7.25 \pm 0.353$ & 0.362 & - & - & - & - & - & - & - & - \\
\hline
\end{tabular}

All values are mean \pm SD; $n=3$; IZ= Inhibition zone in mm (mean value; include $6 \mathrm{~mm}$ diameter of disc), AI= Activity Index (IZ developed by extract/IZ developed by standard), (-) = No activity

Table 2.1: MIC and MBC/MFC of active leaf extracts of A. marmelos and C. papaya

\begin{tabular}{|c|c|c|c|c|c|c|c|}
\hline \multirow[t]{2}{*}{ Pathogens } & \multicolumn{4}{|c|}{ Extracts of leaf of $A$. marmelos } & \multicolumn{3}{|c|}{ Extracts of leaf of $C$. papaya } \\
\hline & Water & & Methanol & Pet ether & Water & Methanol & Pet ether \\
\hline B. subtillis & MIC & 0.156 & 0.156 & 0.312 & 0.312 & - & - \\
\hline \multirow{2}{*}{ S. aureus } & MBC & 0.312 & 0.312 & 0.625 & 0.625 & - & - \\
\hline & MIC & 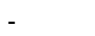 & 0.625 & 0.312 & - & 0.312 & - \\
\hline \multirow[t]{2}{*}{ A. tumifacian } & MBC & - & 1.25 & 0.625 & - & 0.625 & - \\
\hline & MIC & - & - & - & - & - & - \\
\hline \multirow[t]{2}{*}{ K. pneumonae } & MBC & - & - & - & - & - & - \\
\hline & MIC & 0.156 & 0.625 & 0.312 & 0.078 & - & 0.312 \\
\hline \multirow[t]{2}{*}{ R. planticola } & MBC & 0.312 & 1.25 & 0.625 & 0.156 & - & 0.625 \\
\hline & MIC & 0.0195 & - & - & 0.156 & - & - \\
\hline \multirow[t]{2}{*}{ P. aeruginosa } & MBC & 0.039 & - & - & 0.312 & - & - \\
\hline & MIC & 0.312 & 0.312 & 0.312 & - & - & 0.312 \\
\hline \multirow[t]{2}{*}{ A. flavus } & MBC & 0.625 & 0.625 & 0.625 & - & - & 0.625 \\
\hline & MIC & - & 0.625 & 0.312 & - & 0.625 & - \\
\hline \multirow[t]{3}{*}{ T. mentegrophyte } & MFC & - & 1.25 & 0.625 & - & 1.25 & - \\
\hline & MIC & 0.625 & - & - & - & - & - \\
\hline & MFC & 1.25 & - & - & - & - & - \\
\hline
\end{tabular}

MIC = Minimum Inhibitory Concentration (mg/ml), MBC = Minimum Bactericidal Concentration (mg/ml), MFC = Minimum fungicidal Concentration $(\mathrm{mg} / \mathrm{ml})$

Table 2.2: MIC and MBC/MFC of active fruit extracts of $A$. marmelos and $C$. papaya

\begin{tabular}{|c|c|c|c|c|c|c|c|}
\hline \multirow[t]{2}{*}{ Pathogens } & \multicolumn{4}{|c|}{ Extracts of fruit of $A$. marmelos } & \multicolumn{3}{|c|}{ Extracts of fruit of C. papaya } \\
\hline & & Water & Methanol & Pet ether & Water & Methanol & Pet ether \\
\hline \multirow[t]{2}{*}{ B. subtillis } & MIC & 0.039 & 0.078 & 0.078 & 0.312 & - & - \\
\hline & MBC & 0.078 & 0.156 & 0.156 & 0.625 & - & - \\
\hline \multirow[t]{2}{*}{ S. aureus } & MIC & 0.156 & 0.312 & - & 0.312 & - & - \\
\hline & MBC & 0.312 & 0.625 & - & 0.625 & - & - \\
\hline \multirow{2}{*}{ A. tumifacian } & MIC & - & - & - & 0.156 & - & - \\
\hline & $\mathrm{MBC}$ & - & - & - & 0.312 & - & - \\
\hline \multirow[t]{2}{*}{ K. pneumonae } & MIC & 0.0195 & - & 0.625 & 0.078 & 0.625 & - \\
\hline & MBC & 0.039 & - & 1.25 & 0.156 & 1.25 & - \\
\hline \multirow[t]{2}{*}{ R. planticola } & MIC & 0.0195 & 0.156 & 0.625 & 0.312 & - & - \\
\hline & $\mathrm{MBC}$ & 0.039 & 0.312 & 1.25 & 0.625 & - & - \\
\hline \multirow[t]{2}{*}{ P. aeruginosa } & MIC & 0.312 & 0.156 & - & - & - & - \\
\hline & MBC & 0.625 & 0.312 & - & - & - & - \\
\hline \multirow[t]{2}{*}{ A. flavus } & MIC & - & 0.312 & - & - & - & - \\
\hline & MFC & - & 0.625 & - & - & - & - \\
\hline \multirow[t]{2}{*}{ T. mentegrophyte } & MIC & - & 0.625 & - & - & - & - \\
\hline & MFC & - & 1.25 & - & - & - & - \\
\hline
\end{tabular}

$\mathrm{MIC}=$ Minimum Inhibitory Concentration (mg/ml), MBC = Minimum Bactericidal (mg/ml), MFC = Minimum fungicidal Concentration (mg/ml) 
Table 3.1: Total activity of active leaf extracts of Aegle marmelos and Carica papaya

\begin{tabular}{|c|c|c|c|c|c|c|c|c|c|}
\hline \multirow{2}{*}{$\begin{array}{l}\text { Extracts } \\
\text { A. marmeloss }\end{array}$} & \multirow[t]{2}{*}{ Quantity of extracts/g dry weight $\mathrm{mg} / \mathrm{ml}$} & \multicolumn{8}{|c|}{ Total activity $\mathrm{mg} / \mathrm{g}$} \\
\hline & & B. $s$ & S. $a$ & A. $t$ & $K \cdot p$ & $R \cdot p$ & P. $a$ & A. $f$ & T. $m$ \\
\hline W & 150 & 961.53 & 961.53 & - & 961.53 & 7692.30 & 480.76 & - & 240 \\
\hline M & 65 & 416.66 & 208.33 & - & 104 & - & 208.33 & 104 & - \\
\hline $\mathrm{P}$ & 11 & 35.25 & - & - & 35.25 & - & 35.25 & 35.25 & - \\
\hline \multicolumn{10}{|l|}{ C. papaya } \\
\hline W & 112 & 358.97 & - & - & 1436 & 718 & - & - & - \\
\hline M & 282 & - & 903.84 & - & - & - & - & 451.2 & - \\
\hline $\mathrm{P}$ & 12 & - & - & - & 38.46 & - & 38.46 & - & - \\
\hline
\end{tabular}

Total activity= Extract per gram dried plant part/MIC,B. s.-Bacillus subtilis, S. a.-Staphylococcus aureus, A. t.-Agrobacterium tumifacian, K. p.Klebsiella pneumonae, R. p.-Roultellapla nticolla, P. a.-Pseudomonas aeruginosa, A. f.-Aspergillus flavus, T. m.-Trichophyton mentegrophyte, W-Water, M-Methanol, P-Pet ether

Table 3.2: Total activity of active fruit extracts of Aegle marmelos and Carica papaya

\begin{tabular}{|c|c|c|c|c|c|c|c|c|c|}
\hline \multirow{2}{*}{$\begin{array}{l}\text { Extracts } \\
\text { A. marmelos }\end{array}$} & \multirow[t]{2}{*}{ Quantity of extracts mg/g dry weight } & \multicolumn{8}{|c|}{ Total activity $\mathrm{mg} / \mathrm{g}$} \\
\hline & & B. $s$ & S. $a$ & A. $t$ & $K \cdot p$ & $R . p$ & P. $a$ & A. $f$ & T. $m$ \\
\hline W & 36 & 923.07 & 231 & - & 1846.2 & 1846.2 & 115.4 & - & - \\
\hline M & 10 & 128.20 & 115.38 & - & - & 64.10 & 64.10 & 32.05 & 16 \\
\hline $\mathrm{P}$ & 0.5 & 6.41 & - & - & 0.8 & 0.8 & - & - & - \\
\hline \multicolumn{10}{|l|}{ C. papaya } \\
\hline W & 76 & 244 & 244 & 487.17 & 974.35 & 244 & - & - & - \\
\hline M & 6.2 & - & - & - & 9.92 & - & - & - & - \\
\hline $\mathrm{P}$ & 4 & - & - & - & - & - & - & - & - \\
\hline
\end{tabular}

Total activity= Extract per gram dried plant part/MIC, B. s.-Bacillus subtilis, S. a.-Staphylococcus aureus, A. t.-Agrobacterium tumifacian, K. p.Klebsiella pneumonae, R. p.-Roultellaplanticolla, P. a.-Pseudomonas aeruginosa, A. f.-Aspergillus flavus, T. m.-Trichophyton mentegrophyte, W-Water, M-Methanol, P-Pet ether

\section{DISCUSSION}

The increase in microbial resistance specifically in treatment failure is directly responsible for the current increase morbidity and mortality associated with microbial infections. The use of antibiotics that once regarded as one of the biggest discovery of the $20^{\text {th }}$ century is effective on saving many lives against bacterial infection. Unfortunately, uncontrolled use of antibiotics, caused from either patients or prescriptions made without cell cultures analyses, increased the resistance of bacteria [31-32]. Plants can synthesize and preserve a variety of bioactive compounds which are medically important. World health organization reported that more than $80 \%$ of the world population depends on medicinal plants to meet their primary health care need [33]. In India, medicinal plants used as folk remedies and in pharmacological preparation and they are effective in the treatment of infectious diseases while simultaneously mitigating the side effect that is often associated with commonly used antibiotics [34]. The use of medicinal herbs is still a tradition adopted by ethnic communities who are living in undulating plains and at the foothills of dense forest [35]. Hence continuous investigation of plants for their medicinal properties are required for the discovery of new drugs. The present study aims to investigate the comparative analysis of antimicrobial properties of $A$. marmelos and C. papaya. A. marmelos and C. papaya have been previously studied for their antimicrobial activity but the literature available is meager. In the present study, we have found that some of the test extracts showed broad-spectrum antimicrobial activity while some extracts showed negative results. The basis of a varying degree of sensitivity of the test microbes against extracts may be due to the intrinsic tolerance of microorganism and the nature and combination of bioactive compounds present in the crude extracts. The experimental observations confirmed the dependency of antimicrobial activity on both solvent and organism. The literature survey on antimicrobial activity of extracts of both plant yielded only a few reports which detailed mostly on the crude extracts without estimation of MIC, MBC and TA values. The low value of MIC indicates the strong bioefficacy of the plants and hence estimation of these value carries critical importance. In the present investigation IZ, AI, MIC, MBC and TA of each extract were determined and the results were compared for both of the plants. The finding of the present investigation offers a scientific evidence to support that the phyto-compounds are promising in the development of alternative medicines and extracts of $A$. marmelos shows comparatively higher antimicrobial potential than the extracts of C. papaya.

\section{CONCLUSION}

A. marmelos and C. Papaya are the important medicinal plants and are a rich source of bioactive compounds. However, an in-depth study has not been carried out on their biological activity. Therefore, an extensive investigation is needed to exploit bioactive compound from both of the plants for medicinal purpose. Results of the present study evidencedantimicrobial properties of extracts of $A$. marmelos and $C$. Papaya which might be helpful in preventing the development of various diseases and can be used as an alternative system of medicine.

\section{ACKNOWLEDGEMENT}

The authors are thankful to the Head, Department of Botany and University of Rajasthan. Jaipur for providing necessary facilities.

\section{AUTHORS CONTRIBUTION}

The intent, experimental part of the work and writing of the manuscript was done by the first author Ms Jaishree. The intent of the work and the correction of the manuscript was done by the corresponding author prof. Padma Kumar

\section{ABBREVIATION}

millilitre-ml, microliter-ul, millimetre-mm, milligram-mg, gram-g, temperature- ${ }^{\circ} \mathrm{C}$, hours-h

\section{CONFLICT OF INTERESTS}

We declare no conflict of interest

\section{REFERENCES}

1. Weber LD, Pinto FGS, Scur MC, Souza JGL, Costa WF, Leite CW. Chemical composition and antimicrobial and antioxidant activity of essential oil and various plant extracts from Prunus myrtifolia. Afr J Agric Res 2014;9:846-53.

2. Badam L, Bedekar SS, Sonawane KB, Joshi SP. In vitro antiviral activity of beal (corr) upon human coxsackie viruse. J Common Dis 2002;34:88-99. 
3. Kamalakkannan $\mathrm{N}$, Stanely Mainzen Prince P. Antihyperlipidemic effect of Aegle marmelos fruit extract in streptozotocin-induced diabetes in rats. J Sci Food Agric 2005;85:569-73.

4. Arul V, Miyazaki S, Dhananjayan R. Studies on the antiinflammatory, antipyretic and analgesic properties of the leaves of Aegle marmelos Corr. J Ethnopharmacol 2005;96:159-63.

5. Jagetia GC, Venkatesh P, Baliga MS. Aegle marmelos (L.) Correa inhibits the proliferation of transplanted Ehrlichascites carcinoma in mice. Biol Pharm Bull 2005;28:58-64.

6. Kamalakkannan N, Prince PSM. Hypoglycaemic effect of water extracts of Aegle marmelos fruits in streptozotocin diabetic rats. J Ethnopharmacol 2003;87:207-10.

7. Rajadurai M, Padmanabhan M, Prince PSM. Effect of Aegle marmelos leaf extract and alpha-tocopherol on lipid peroxidation and antioxidants in isoproterenol-induced myocardial infarction in rats. Cardiology 2005;46:40-5.

8. Sabu MC, Kuttan R. Antidiabetic activity of Aegle marmelos and its relationship with its antioxidant properties. Indian J Physiol Pharmacol 2004;48:81-8.

9. Saradha Jyothi K, Subba Rao B. Antibacterial activity of extracts from Aegle marmelos against standard pathogenic bacterial strains. Int J Pharm Tech Res 2010;2:1824-6.

10. Sur TK, Pandit S, Pramanik T. Antispermatogenic activity of leaves of Aegle marmelos corr. in albino rats: a preliminary report. Biomedicine 1999;19:199-202.

11. Yen GC, Duh PD, Tsai CL. Relationship between antioxidant activity and maturity of peanut hulls. J Agric Food Chem 1993;5:67-70.

12. Aevind G, Debjit B, Duraivel S, Harish G. Traditional and medicinal uses of Carica papaya. J Med Plants Stud 2013;1:7-15.

13. Sinhalagoda LCAD, Susuji W, Roshitha NW, Rajapakse PVJR, Senanayake AMK. Does Carica papaya increase the platelets count? An experimental study in a murine model. Asian Pac J Trop Biomed 2013;7:720-4.

14. Lowy FD. Staphylococcus aureus infections. N Engl J Med 1998;339:520-32.

15. Hu AY, Leslie KA, Baskette J, Elsayed S. Raoultella planticola bacteraemia. J Med Microbiol 2012;61:1488-9.

16. O'Connell K, Kelly J, Niriain UA. A rare case of soft-tissue infection caused by Raoultella planticola. Case Rep Med 2010. Doi:10.1155/2010/134086.

17. Alves MS, Riley LW, Moreira BM. A case of severe pancreatitis complicated by Raoultella planticola infection. J Med Microbiol 2007;56:696-8.

18. Olson DS Jr, Asare K, Lyons M, Hofinger DM. A novel case of Raoultella planticola urinary tract infection. Infection 2013;41:259-61.
19. Pirnay JP, Bilocq F, Pot B, Cornelis P, Zizi M, Van Eldere J, et al. Pseudomonas aeruginosa population structure revisited. PloS One 2009;4:e7740.

20. Silby MW, Winstanley C, Godfrey SA, Levy SB, Jackson RW. Pseudomonas genomes: diverse and adaptable. FEMS Microbiol Rev 2011;35:652-80.

21. Bonomo RA, Szabo D. Mechanisms of multidrug resistance in Acinetobacter species and Pseudomonas aeruginosa. Clin Infect Dis 2006;43:S49-56.

22. Hedayati MT, Pasqualotto AC, Warn PA, Bowyer P, Denning DW. Aspergillus flavus: human pathogen, allergen and mycotoxin producer. Microbiology 2007;153:1677-92.

23. Saferstein HL, Blank F. Tineacorporis caused by Trichophyton mentagrophytes var, granulosum. Mycopathology 1967;31:267-72.

24. Van Rooij P, Detandt M, Nolard. Trichophyton mentagrophytes of rabbit various extracts of Centaureacankiriense A. Duran and H. Duman. Afr J Microbiol Res 2006;4:608-12.

25. Sanchez-Castellanos ME, Mayrga-Rodrigues JA, Sandoval-Tress C, Hernandz-Torres M. Tinea incognito due to Tricophyton mentagrophyte. Mycoses 2007;50:85-7.

26. Harborne JB. Phytochemical methods, Chapmen and Hall 2edn London, Newyork; 1984. p. 5-6.

27. Andrews JM. BSAC standardized disc susceptibility testing method. J Antimicrobial Chemothe 2001;4:43-57.

28. Gould JC, Bowie JH. The determination of bacterial of the sensitivity of antibiotics. Edinberg Med J 1952;59:178-99.

29. Basri DF, Fan SH. The potential of aqueous and acetone extracts of gall of Quercus infectoria as antibacterial agents. Indian J Pharmocol 2005;37:26-9.

30. Eloff JN. Qualifying the bioactivity of plant extracts during screening and bioassay-guided fractionation. Phytomedicine 2004;113:70-1.

31. Eloff JN. On expressing the antibacterial activity of plant extracts-a small first step in applying scientific knowledge to rural primary health care. S Afr J Sci 2000;96:116-8.

32. Peterson LR, Dalhoff A. Towards targeted prescribing: will the cure for antimicrobial resistance be specific, directed therapy through improved diagnostic testing? J Antimicro Chemother 2004;53:902-5

33. WHO traditional medicine: growing need and potential on medicines. p. 1, World health Organization, Geneva; 2002.

34. Iwu MW, Duncan AR, Okunji CO. New antimicrobials of plant origin. In: Janick J, Ed. Perspectives on New Crops and New Uses, ASHS Press: Alexandria; 1999. p. 457-62.

35. Anitha Jegadeeshwari L, Dharathi N, Vidhya Lakshmi D, Vasanth Kumar E, Nagendra Gandhi N. Tribal plants and their inborn antimicrobial activities. Asian J Pharm Clin Res 2017;7:31-7. 